\title{
Agricultural Landscapes in Brandenburg, Germany: An Analysis of Characteristics and Spatial Patterns
}

\author{
Saskia Wolff ${ }^{1} \mathbb{D} \cdot$ Silke Hüttel $^{2} \cdot$ Claas Nendel $^{3,4} \cdot$ Tobia Lakes $^{1,3}$
}

Received: 30 November 2020 / Revised: 15 February 2021 / Accepted: 13 March 2021 / Published online: 20 March 2021

(c) The Author(s) 2021

\begin{abstract}
The increasing demand for agricultural commodities for food and energy purposes has led to intensified agricultural land management, along with the homogenization of landscapes, adverse biodiversity effects and robustness of landscapes regarding the provision of ecosystem services. At the same time, subsidized organic agriculture and extensive grassland use supports the provision of ecosystem services. Yet little is understood about how to evaluate a landscape's potential to contribute to protecting and enhancing biodiversity and ecosystem services. To address this gap, we use plot-level data from the Integrated Administration and Control System (IACS) for Germany's federal state of Brandenburg, and based on a two-step cluster analysis, we identify six types of agricultural landscapes. These clusters differ in landscape structure, diversity and measures for agricultural land management intensity. Agricultural land in Brandenburg is dominated by high shares of cropland but fragmented differently. Lands under organic management and those with a high share of maize show strong spatial autocorrelation, pointing to local clusters. Identification of different types of landscapes permits locally- and region-adapted designs of environmental and agricultural policy measures improves outcome-oriented environmental policy impact evaluation and landscape planning. Our approach allows transferability to other EU regions.
\end{abstract}

\section{Article Highlights}

- Analysis of (landscape) metrics indicating agricultural landscape structure, landscape diversity and management using plot-based agricultural data.

- Identification of agricultural landscape types through a two-step data-driven cluster analysis deriving six types for Brandenburg, Germany.

- Highly transferable approach and relevant results for better-tailored monitoring and policy implementation on local level.

Keywords Agricultural land use $\cdot$ Landscape metrics $\cdot$ Cluster analysis $\cdot$ IACS data $\cdot$ Land-use intensity

Saskia Wolff

saskia.wolff@geo.hu-berlin.de

1 Geography Department, Applied Geoinformation Science Lab, Humboldt-Universität Zu Berlin, Unter den Linden 6, 10099 Berlin, Germany

2 Production Economics Group, Institute of Food and Resource Economics, University of Bonn, Meckenheimer Allee 174, 53115 Bonn, Germany

3 Integrative Research Institute On Transformations of Human-Environment Systems (IRI THESys), Humboldt-Universität Zu Berlin, Unter den Linden 6, 10099 Berlin, Germany

4 Leibniz Centre for Agricultural Landscape Research (ZALF), Eberswalder Straße 84, 15374 Müncheberg, Germany

\section{Introduction}

A sustainable pathway is needed to increase agricultural production and achieve food security in the future, while simultaneously reducing the adverse environmental effects of agricultural production. The provision of ecosystem services from agricultural land, in particular, needs to be improved, and this has been increasingly highlighted by science and enacted in policy changes (Schaller et al. 2018). European agricultural landscapes have experienced diverging shifts towards intensification and specialization on the one hand, and marginalisation and abandonment on the other hand, and these dual trends are expected to continue into the 
future (Lambin et al. 2000; Monteleone et al. 2018; Stoate et al. 2009). Marginal agricultural landscapes, characterised by unfavourable biophysical conditions such as steep slopes, shallow and/or poor soils and inferior accessibility (Harvolk et al. 2014; Lüker-Jans et al. 2016), can increase biodiversity and habitat richness. This, however, requires low-input production, wide crop rotations, permanent grassland and small-parcelled mosaics. High Nature Value (HNV) farming systems, typical for such landscapes, are essential to biodiversity conservation and the provision of ecosystem services (Lomba et al. 2020; Strohbach et al. 2015). Intensive and traditional agricultural production, however, rests on homogenous landscapes, i.e. larger plots without landscape elements that could provide sufficient habitat structure or prevent soil erosion (Tscharntke et al. 2005).

Our research focuses on the eastern German Federal State of Brandenburg, where large-scale agricultural land use shapes the landscape. As in many other post-communist regions, large-scale agriculture persisted despite fragmented land ownership after restitution following German reunification (Hartvigsen 2014). Along with the large-scale farming structure, Brandenburg's agricultural landscape is characterized by homogenisation and production intensification, both of which are associated with a decrease in biodiversity and adverse environmental effects, i.e. a decrease in soil and water quality (Thomson et al. 2019). These trends continue despite the EU's efforts to increase financial support for sustainable land management practices within the Common Agricultural Policy (CAP). Concerns over whether these efforts have been able to impede adverse landscape structures lead to questions regarding how to quantitatively assess landscapes' functioning so as to preserve and enhance biodiversity, habitats and thus, ecosystem service provision.

Quantitative landscape metrics characterise and allow comparison of agricultural landscapes across space and over time (Uuemaa et al. 2013). Typically, the number, size, shape and arrangement of patches of different land use/land cover types are used to describe a landscape's structure, composition and dynamics (Lausch and Herzog 2002). Recent metrics also include the area under cultivation, mean patch size and Shannon's Diversity Index as an agrobiodiversity indicator (Uthes et al. 2020) to characterize agricultural land use and management intensity (Schlesinger and Drescher 2018). Other measures of agricultural land management intensity rely on input use intensity, including labour or capital, management practices, output quantities such as per-hectare yields (Shriar, 2000), or the dependence on industrial goods such as machinery and fertiliser (Temme and Verburg 2011; Zasada et al. 2013). A conceptual framework to quantify and analyse land-use intensity proposed by Erb et al. (2013) integrated three dimensions: input intensity, output intensity and the associated system-level impacts of land-based production (e.g. changes in carbon storage or biodiversity). Estel et al. (2016) summarized that particularly in mapping indicators of cropland use intensity substantial progress has been made. Intensity indicators included yield gaps, fertilizer use, human appropriation of net primary production, field size or the extent of irrigated agriculture or tillage (Estel et al. 2016). The study by Estel et al. (2016) maps and characterizes cropping systems based on the MODIS Normalized Difference Vegetation Index (NDVI) time series and self-organizing maps. The results correspond well with indicators for agricultural intensity, such as nitrogen inputs or yields. Rega et al. (2020) combine the mapping of cropping systems with an indicator of management intensity to classify agricultural land across Europe. Many of these studies, however, have limited generalisability given restrictions on available data to small areas, regions or selected farms.

The Integrated Administration and Control System's (IACS) dataset that is used to monitor and control the flow of payments for which farmers apply as part of the CAP offers promising applications to carry out plot-based characterisations of different types of agricultural landscapes. Several studies have successfully used this dataset to analyse agricultural land-use change (Lüker-Jans et al. 2016; Tomlinson et al. 2018) and to characterise farms based on crop choice and land use (Lomba et al. 2017; Uthes et al. 2020). On a broader scale, landscape archetypes and zones on a European or global level have also been identified and discussed in several studies (Eisenack et al. 2019; Levers et al. 2018; Oberlack et al. 2019; Václavík et al. 2013). This research, however, did thus far not take into account detailed regional specifications.

The aim of this paper is to close this gap by first identifying and characterising different types of agricultural landscapes based on an integrative approach that jointly acknowledges landscape structure, diversity and management derived from plot-based information, and second, by depicting their spatial patterns. We illustrate our approach for the Federal State of Brandenburg and pose the following research questions:

RQ1: How can agricultural landscapes be characterized in terms of landscape structure, diversity and management on a small scale. What spatial patterns can be detected?

RQ2: How can regionally specific agricultural landscape types be identified? Which spatial concentration of those types exist?

Our analysis relies on IACS data for Brandenburg and uses metrics built from a combination of agricultural landscape structure, diversity and management indicators rather than single-variable metrics. We thereby include detailed regional specifications in contrast to existing classifications for Brandenburg, i.e. agro-ecological zones (Landbaugebiete), defined by site conditions and the resulting productivity (Landesamt für Ländliche 
Entwicklung, Landwirtschaft und Flurneuordnung, 2016) or single-variable crop and livestock information provided by the Thünen Atlas (Thünen Institut 2014). We are thus able to capture different dimensions of agricultural landscapes which may indicate or be used as a proxy for selected ecosystem services (ESS), e.g. habitat richness or biodiversity. While landscape metrics are most frequently applied to grids and administrative areas, we use hexagons, which have been shown to better capture spatially continuous phenomena, such as agricultural landscapes, due to their spatial smoothing effect towards the edges (Birch et al. 2007; Schindler et al. 2008).

The outcomes of this study provide important insights. First, integrated agricultural landscape characteristics can be used to develop environmental and agricultural policies that are better tailored to local and regional characteristics. Second, the results of this study can subsequently be used to prioritize areas and set the scope for measures regarding agricultural land use, particularly enforcing multifunctional agricultural landscapes. Last, our methodological approach allows transferability to other EU regions, where identification of different types of landscapes offers locally- and regionally-adapted designs of environmental and agricultural policy measures, environmental policy impact evaluation and landscape planning.

\section{Material and Methods}

\section{Study Region}

The state of Brandenburg is located in north-eastern Germany, covers $29,640 \mathrm{~km}^{2}$ and is a heavily agricultural state, with approximately $45 \%$ of its area comprised of agricultural land (Amt für Statistik Berlin-Brandenburg 2016)—making it an ideal setting to study landscape composition. $12 \%$ of Brandenburg's agricultural area is dedicated to organic agriculture, which is relatively high compared to other German states, and has been steadily increasing (MLUK 2019). Nevertheless, the utilized agricultural area has remained constant, with about $77 \%$ cropland and $23 \%$ permanent grassland (Troegel and Schulz 2018). Brandenburg completely surrounds Germany's capital city of Berlin (Fig. 1), where land use and its composition are heavily influenced by strong urbanization trends such as demand for residential land in the suburban areas. Demand for regional food production in the neighbouring state has been growing, as has the use of cropland for renewable energy production (Gutzler et al. (2015), leading to considerable increases in maize production for subsidized biogas fermentation in Brandenburg (Federal Environmental Ministry 2000).

Brandenburg's agricultural land exhibits a high share of low-quality soils; almost two-thirds are sandy and sandyloamy soils. According to Gutzler et al. (2015), this situation, paired with low rainfall (on average, less than $600 \mathrm{~mm} /$

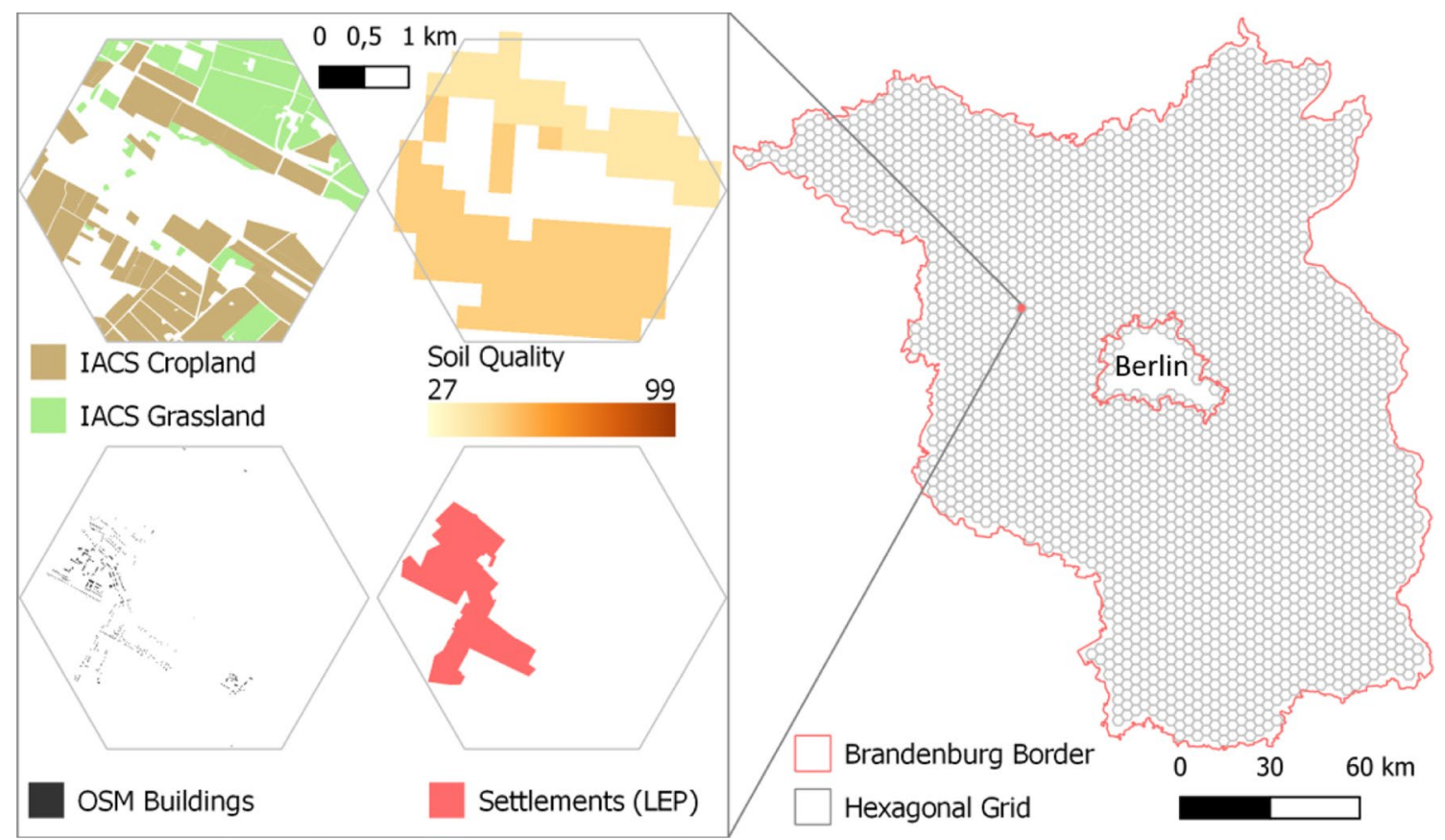

Fig. 1 Input data source samples and hexagonal grid in the study area Brandenburg, Germany 
year), makes agricultural production challenging. This is one reason why Brandenburg farmers either produce in the organic niche, benefiting from the high prices paid in Berlin for regional, organic food, or apply a high level of technology, including heavy-duty machinery and intensive use of fertilizers and agrochemicals (Gutzler et al. 2015). Maize replaced rye as the main crop in 2013 , followed by wheat and rapeseed (Troegel and Schulz 2018). As in all eastern German states, agricultural in Brandenburg is dominated by large farm enterprises with an average size of approximately 250 hectares, four times the German average (Gutzler et al. 2015; Troegel and Schulz 2018). Livestock production has been in continuous decline in Brandenburg; according to the most recent available agricultural census, its livestock density in 2010 was a low 0.4 livestock units (LU) per hectare in comparison to other federal states, such as Lower Saxony's 1.1 LU per hectare (Statistisches Bundesamt 2019). We, therefore, focus on cropland and grassland in our analysis. Furthermore, in contrast to Uthes et al. (2020), we propose an areal characterisation of landscapes instead of farming systems where livestock numbers are more relevant.

As a base for our indicator and cluster calculation, we created a hexagonal grid with a cell size of $10 \mathrm{~km}^{2}(N=2836$, Fig. 1). The size of the cells captured the landscape level and the spatial configuration of plots within each cell (mean plot size $=7.9$ ha). Since administrative areas vary in size and form, the hexagonal grid provides a smoother surface for analysis (Birch et al. 2007; Schindler et al. 2008) and has been applied in studies using landscape metrics for characterizing agricultural landscapes (Griffith et al. 2000). We selected only those cells that are located entirely within the Brandenburg state, including overlaps with Berlin administrative areas.

\section{Data}

We used plot-based information on the cultivation of agriculture in Brandenburg in 2018 from the IACS to identify agricultural characteristics. Farms apply for area-based payments to ensure income support according to EU CAP regulations, managed and controlled in a standardised way in all EU member states through IACS. In Brandenburg, the baseline map for the registration is a digital cadastre of field blocks established in 2015. The field block cadastre covers the agricultural area in Brandenburg that is eligible for EU subsidies and is updated based on orthophotos. A field block is a coherent agricultural area surrounded by permanent borders (e.g. roads, paths, trees) with a predominantly uniform primary land use. One or more farmers can use a field block, meaning that the area of one field block may be split between each farmer who applies for subsidies. As a result, the georeferenced agricultural land use data covers only those plots for which farmers applied for subsidies in 2018. The outlines of the plots are generally aligned with the underlying field blocks, but they may have been edited by the farmer due to the specific land use in a specific year. Hence, the size and outlines of plots registered for subsidies can change over time. In addition to agricultural use at the plot level, landscape elements located in a field block, such as hedges, rows of trees and single trees, are also registered. In Brandenburg, landscape elements were registered and located with a single point until 2016, but now they are digitised with spatial outlines (e.g. groups of trees). We, therefore, focused on the categories of grassland, cropland and landscape element, which were assigned based on cultivated crops (Kulturart) for 2018. These landscape elements include ecological priority areas for which farms can get extra support within the EU CAP. However, we did not include landscape elements in the final cluster analysis. All subcategories were then aggregated to the categories: cropland, grassland and landscape elements (Fig. 1).

To account for specific types of arable land use, we identified plots that were likely to have been cultivated without crop rotation and used maize as a specific crop type. We also included information about whether a plot is under organic or conventional management, both of which are indicated in the IACS data.

In addition to IACS data, we used the Open Street Map (OSM) data and regional planning data (settlement locations) and soil quality (Fig. 1). We used the OSM data for all building footprints in Brandenburg from September 2019 to assess the degree of urbanisation in each hexagon. OSM is an open-source, crowd-sourced mapping platform that has high coverage and good quality in countries such as Germany (Fan et al. 2014; Jokar Arsanjani et al. 2015). We used April 2019 settlement data from the Landesentwicklungsplan Hauptstadtregion Berlin Brandenburg for calculating the mean Euclidean distance to settlements for each cell. The Bundesanstalt für Geowissenschaften und Rohstoffe (2014) provides a soil quality rating (SQR) on a $0-100$ point scale (Mueller et al. 2007), which indicates a rough estimate for crop yield potential. Soil quality points suggest the potential productivity and are an official measure in Germany that was constructed to combine pedologic, scientific and agronomic considerations within one measure. A low (high) number represents very low (high) productivity (BMJV 2007; Scheffer et al. 2010).

\section{Indicator Calculation, Metrics and Spatial Patterns}

To answer RQ1, we selected a set of landscape metrics to characterise agricultural landscapes based on a literature review according to three categories (Table 1).

Landscape structure: median plot size (ha), edge density (calculated as a share of the total hexagon area in $\mathrm{km} / 10$ 
Table 1 Metrics to describe landscape structure, diversity and management with description of indicators, calculation of metrics and data sources

\begin{tabular}{|c|c|c|c|}
\hline Metric & Indicator & Calculation & Data source \\
\hline \multicolumn{4}{|l|}{ Landscape structure } \\
\hline Plot size & Spatial configuration of plots & $\begin{array}{l}\text { Median plot size in each hexagon } \\
\text { area (ha) }\end{array}$ & $\begin{array}{l}\text { Integrated Administration Control } \\
\text { System (IACS) }\end{array}$ \\
\hline Edge density & $\begin{array}{l}\text { Habitat diversity, fragmentation of } \\
\text { agircultural landscape }\end{array}$ & $\begin{array}{l}\text { Total plot edge length per hexagon } \\
\text { area }\left(\mathrm{km} / 10 \mathrm{~km}^{2}\right)\end{array}$ & IACS \\
\hline Number of buildings & Urbanity & $\begin{array}{l}\text { Count building per hexagon area } \\
(N)\end{array}$ & Open Street Map (OSM) \\
\hline Distance to settlements & Urbanity & $\begin{array}{l}\text { Mean Euclidean disctance for each } \\
\text { hexagon }(\mathrm{km})\end{array}$ & $\begin{array}{l}\text { Settlement data from "Landesent- } \\
\text { wicklungsplan Hauptstadtregion } \\
\text { Berlin Brandenburg" }\end{array}$ \\
\hline \multicolumn{4}{|l|}{ Landscape diversity } \\
\hline Share of agriculture & Landscape heterogeneity & $\begin{array}{l}\text { Share of agricultural area per } \\
\text { hexagon }(\%)\end{array}$ & IACS \\
\hline Shannon Diversity Index (SDI) & Agro-biodiversity & $\begin{array}{l}\mathrm{SDI}=-\sum_{i=1}^{n} p_{i} \ln p_{i} \\
p_{i}=\text { share }(\%) \text { of crop/crop and } \\
\text { usage i in total agr. area } \\
\ln p_{i}=\text { natural logarithm of } p_{i}\end{array}$ & IACS \\
\hline Share of landscape elements & Habitat diversity & $\begin{array}{l}\text { Share of landscape element area } \\
\text { per hexagon }(\%)\end{array}$ & IACS \\
\hline \multicolumn{4}{|l|}{ Management } \\
\hline Share of organic agriculture & Sustainable agricultural production & $\begin{array}{l}\text { Share of organicically utilized area } \\
\text { per hexagon }(\%)\end{array}$ & IACS \\
\hline Share of cropland & Potential agricultural intensity & $\begin{array}{l}\text { Share of cropland area per hexagon } \\
(\%)\end{array}$ & IACS \\
\hline Share of maize & Potential cropland intensity & $\begin{array}{l}\text { Share of the area under maize } \\
\text { cultivation per hexagon }(\%)\end{array}$ & IACS \\
\hline Soil quality & Yield potential & $\begin{array}{l}\text { Mean soil quality point per hexa- } \\
\text { gon }\end{array}$ & Soil Quality Rating (SQR) \\
\hline
\end{tabular}

$\mathrm{km}^{2}$ ), number of buildings $(N)$ and mean distance to settlements $(\mathrm{km})$.

Landscape diversity: agriculture share of total hexagon area (\%), Shannon Diversity Index (SDI), share of landscape elements in a total agricultural area (\%).

Management: share of organic of total agricultural area (\%), share of cropland of total agricultural area (\%), share of maize of total agricultural area (\%), soil quality (values from 0-100).

We calculated the respective indicator values for the year 2018 at the aggregated level of the hexagons. We focused on measures to describe agricultural land use, management, agricultural intensity and diversity and spatial configuration.

Plot size captures the spatial configuration of plots and is frequently used to characterise agricultural landscapes (Dengler 2009; van der Zanden et al. 2016). We calculated median plot size within hexagons from the reported management units in the IACS data by using the centroid of the plots, considering each plot only once even though it might have overlapped between two cells.
The ecological role of habitat diversity and plot edges for farmland biodiversity (including functional biodiversity) has been demonstrated by several authors (Benton et al. 2003; Burel and Baudry 2005; Weissteiner et al. 2016). We, therefore, calculated edge densities and the SDI. Edge density characterises the fragmentation of the agricultural landscape, i.e. with increasing edge density, the number of farmland patches increase and their patch size decreases $(\mathrm{Su}$ et al. 2014).

Organic agriculture is a production type in which mineral fertiliser and synthetic pesticide usage are subject to stricter regulations than in conventional agriculture (Gabriel et al. 2010). Because organic production is considered less harmful to the environment and key for more sustainable agricultural production, it has been included as a share of organic agriculture as an indicator.

To differentiate between cropland and grassland, we included the share of cropland of the total agricultural area, following the argument that most grasslands in eastern Germany are managed rather extensively (Matzdorf et al. 2008). Though grasslands can also be managed intensively, 
particularly in regions with high livestock densities, Brandenburg is characterised by few ruminant livestock and rather extensively used grasslands under agro-environmental measures, whereby farmers receive additional compensation payments through the EU CAP for extensively-managed grasslands (Matzdorf et al. 2008).

We measured cropland intensity by the share of maize that is likely to be used for biogas and cultivated as a longterm, self-following crop, i.e. without crop rotation (Gutzler et al. 2015; Lüker-Jans et al. 2016). We included all maize types (i.e. silage maize and corn maize) in our analysis. According to the German expert group for renewable energy (FNR 2013), the expansion of maize monocultures (no mixed cultivation on a plot) is expected to be on par with the intensification of crop production (Vergara and Lakes 2019). Areas with a high share of maize may indicate intensive production of crops for biogas, which often comes at the expense of food production areas (Grundmann and Klauss 2014; Lüker-Jans et al. 2016).

The SDI, as a measure of agrobiodiversity, is widely used (Uthes et al. 2020; Vaz et al. 2014). It considers the abundance of different crop types. We calculated the SDI for all listed cultivated plants within the IACS data $(N=158)$ according to the following formula:

$\mathrm{SDI}=-\sum_{i=1}^{n} p_{i} \ln p_{i}$

where

$p_{i}=$ share $(\%)$ of crop/crop and usage $i$ in a total agricultural area

$\ln p_{i}=$ natural logarithm of $\mathrm{p}_{\mathrm{i}}$

The diversity measure equals minus the sum, across all crop types, of the proportional abundance of each crop type, multiplied by that proportion (Griffith et al. 2000).

According to Uthes et al. (2020), landscape elements such as hedge or tree rows are important features for a diverse landscape structure. We thus calculated the share of landscape elements in the total agricultural area within each hexagon.

We used the SQR as a measure for yield potential, which has often been used in land market analyses, such as those of Hüttel et al. (2016) and Ritter et al. (2015).

To assess the degree of urbanisation, we calculated the number of buildings in each hexagon and the mean distance to settlements. According to $\mathrm{Su}$ et al. (2011), proximity to urban centres parallels the intensity of urbanisation and the decrease in human influences on the environment. Additionally, Piorr et al. (2018) emphasise that agricultural landscapes 'differ in the way they are influenced by the proximity to urban areas, being part of functional urban-rural linkages, urban pressures and opportunities', e.g. regarding the farming systems and the involvement of (urban) communities.
For visualization of the results, we classified the metrics share of agriculture, cropland, maize and organic agriculture by equal intervals in $20 \%$ steps. For the indicators related to the number of buildings, distance to settlements, soil quality, median plot size, edge density and the SDI, we used natural breaks (jenks) for classification.

To identify spatial patterns, we calculated the spatial autocorrelation values for all single metrics with continuous values. We used Global Moran's I statistics, which characterise the spatial dependency of values between the hexagons (Moran 1950). We used all six neighbours (Queen's contiguity) of each hexagon. The value of Moran's I ranges from -1 (perfect negative autocorrelation) to 1 (perfect positive autocorrelation), with 0 indicating spatial randomness (Moran 1950).

\section{Cluster Analysis to Identify Agricultural Landscape Types and Spatial Concentrations}

To answer RQ2, we applied a two-step cluster analysis using selected metrics to identify different types of agricultural landscapes in Brandenburg.

Lausch and Herzog (2002) emphasise that when working with landscape metrics, one is confronted with the question of which indicators are relevant for the area and the problem under investigation. We, therefore, determined Spearman's correlation coefficients to reduce redundancies (Lausch and Herzog 2002). After the Spearman correlation analysis, eight selected indicators showed values $<0.4$ (Fig. 9 in Appendix). However, we relied on seven input variables for the cluster analysis, having excluded the share of landscape elements. This indicator was not included because the values are generally very low in the hexagonal grids, with low variance except for a few outliers (65\% of all hexagons have $\mathrm{a}<1 \%$ share), and if included in the cluster analysis, the results showed no variance within clusters. The final cluster analysis input indicators included soil quality, number of buildings, edge density, shares of organic agriculture, cropland and maize, and median plot size for each hexagon in 2018 (Fig. 2).

We followed the approach of Lüker-Jans et al. (2016), that characterised agricultural land use patterns using k-means clustering. Here, we applied a two-step cluster analysis because of its ability to deal with large datasets, including variables that are not normally distributed, and the possibility of automatically determining the optimum number of clusters (Chiu et al. 2001). In the first pre-clustering step, the Bayesian information criterion (BIC) was calculated for each cluster, which was then used to generate an initial estimate of the number of clusters. The second step refined the initial estimate by determining the greatest change in distance between the two closest clusters in each hierarchical clustering stage (Chiu et al. 2001). We note that 178 hexagons could not be clustered due 


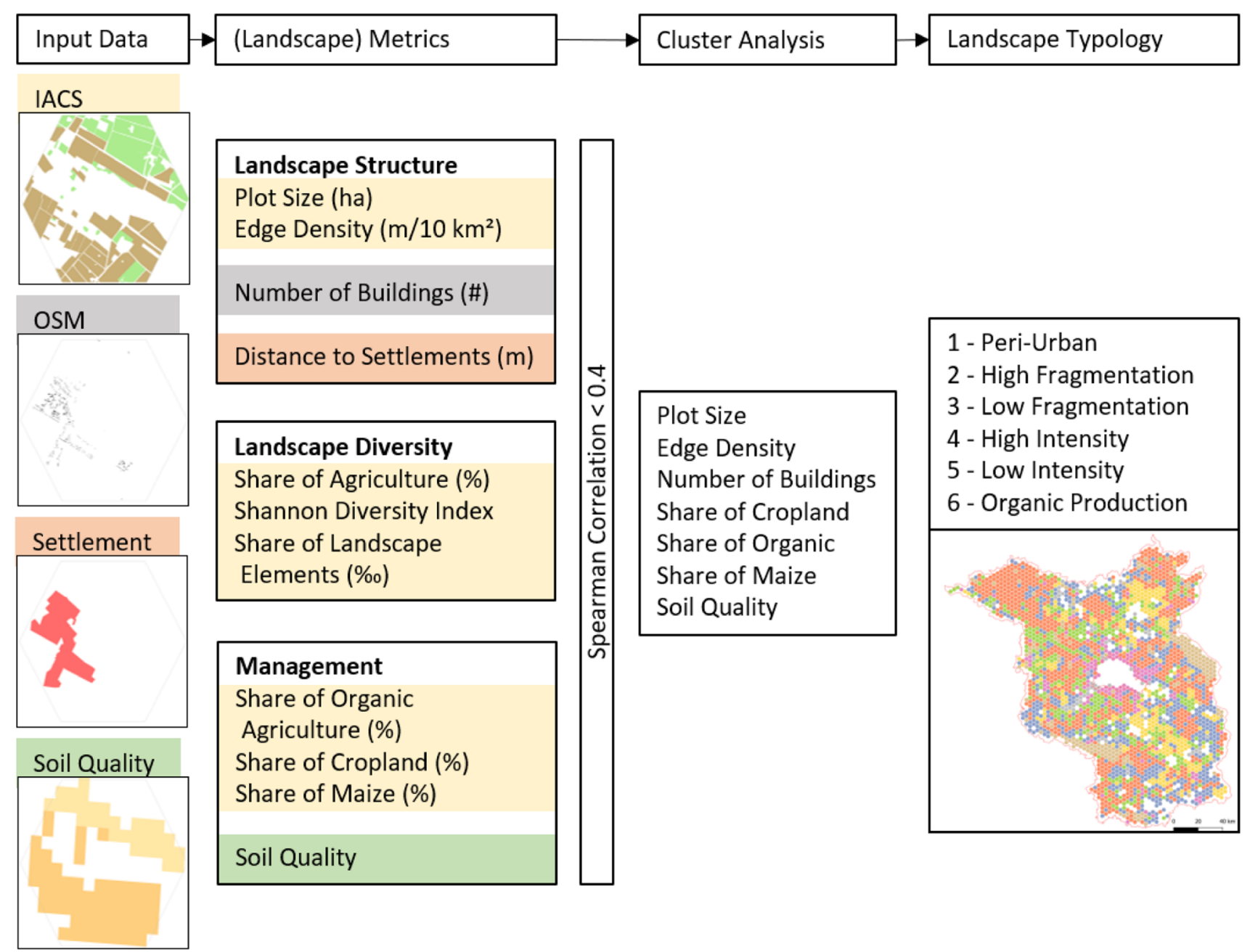

Fig. 2 Workflow including data and processing steps from indicator calculation to cluster analysis for identifying agricultural landscape types

to missing soil quality data in those cells; consequently, no type could be assigned.

For goodness assessment of the cluster number, the model fit was evaluated using the silhouette coefficient, which is a measure of the cohesion and separation of clusters. A value above 0.2 indicates a fair cluster quality (Tkaczynski 2017).

Since the cluster values are categorical, we calculated the join count to determine the degree of spatial concentration or dispersion among a set of spatially adjacent polygons (Plant 2012). To calculate the join count for each cluster value, we set the reference cluster value to 1 and all other cluster values to 0 .

\section{Results and Discussion}

\section{Characteristics and Spatial Patterns of the Agricultural Landscape in Brandenburg}

With respect to RQ1 and regard to the categories landscape structure, landscape diversity and management, we found the following results. For brevity, total values (min, max, median and standard deviation) for all hexagons are provided in Table 3 in the Appendix. 


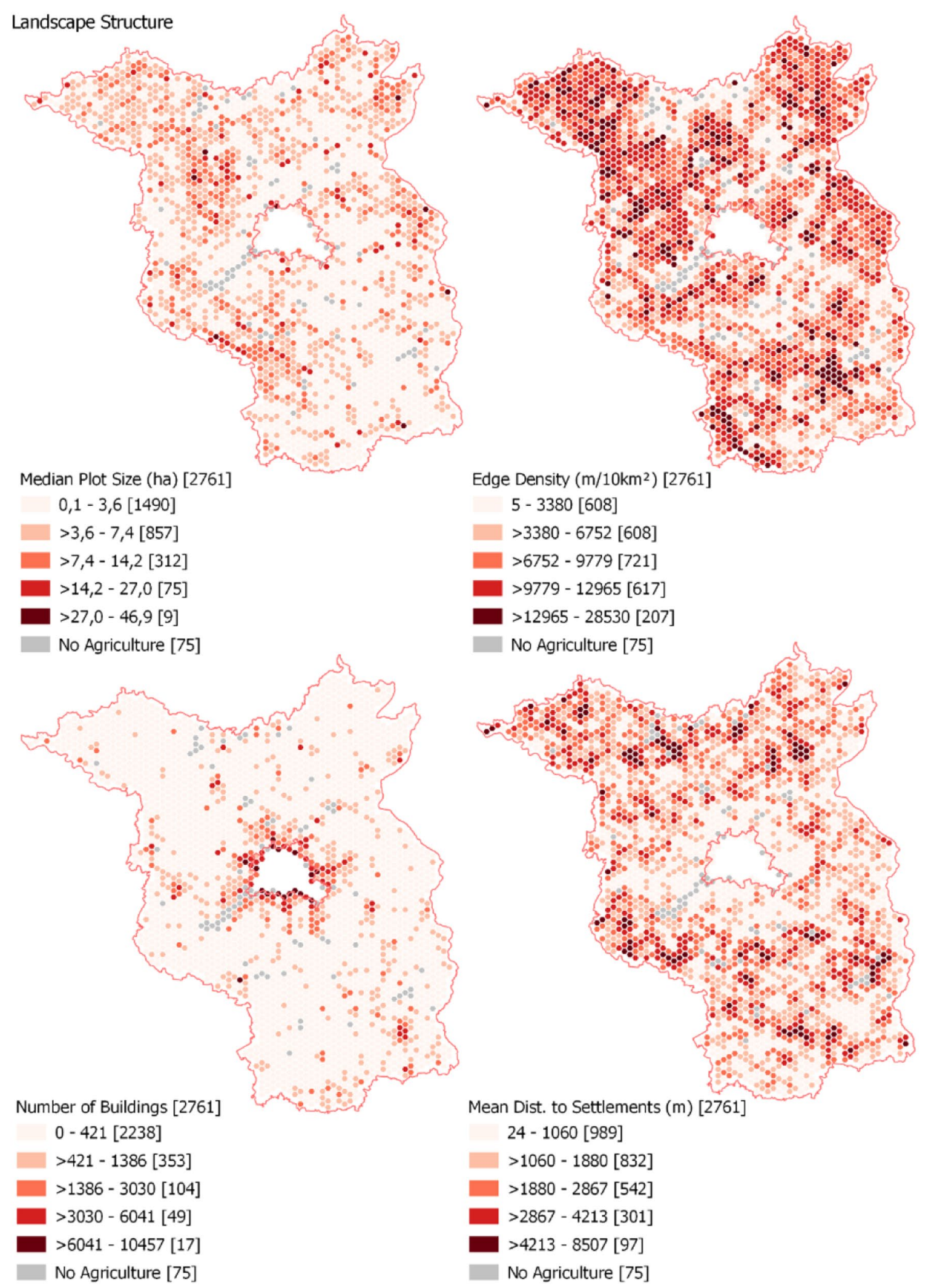

Fig. 3 Maps for landscape structure indicators including median plot size (ha), edge density $\left(\mathrm{m} / 10 \mathrm{~km}^{2}\right)$, number of buildings (\#) and mean distance to settlements (m) 


\section{Landscape structure (Fig. 3)}

Most hexagonal cells show a rather low median plot size between 0.1 ha and 7.4 ha $(N=2347)$. However, median plot sizes can reach up to 27.0 ha to 46.9 ha $(\mathrm{N}=9)$ which include both, cropland and grassland plots. The ecological value of certain plot sizes depends on the agricultural use; according to Crist and Peters (2014), larger and older plots of grassland might support greater biodiversity of insect species than do smaller plots. Other studies suggest that agricultural diversification - the compositional heterogeneity of crops within a landscape-supports an increase in both biodiversity and yields (Burchfield et al. 2019; Thomson et al. 2019).

Edge density represents the composition of plots. Hexagons that did not have strictly rectangular plot shapes showed higher edge density values. From this, we infer that such shapes might increase agricultural landscape diversity, in line with Uthes et al. (2020). Edges might operate as zones for ecologically valuable elements, such as hedges or tree rows.

Brandenburg contained many rural hexagons with a low number $(0-421)$ of buildings $(N=2238)$. The highest settlement densities (number of buildings $>6041$ ) were in cells adjacent to Berlin and to regional centres such as Neuruppin, Schwedt/Oder, Fürstenwalde, Cottbus and Jüterbog $(N=17)$. At the same time, most of the hexagons were characterised by short mean distances to the nearest settlement associated with high spatial autocorrelation (Moran's $I=0.51$ ). Approximately $66 \%$ of cells showed a mean distance below $2 \mathrm{~km}$.

\section{Landscape diversity (Fig. 4)}

The share of agricultural area per cell was evenly distributed between the $20 \%$ step-classes, with the exception of those with a very high agricultural share ( $>80 \%, N=349$ of 2761). The highest agricultural shares were found in cells with the highest values for mean soil quality ( $>62$ ). Only 75 hexagons contained no agricultural land at all and were instead covered by forest, urban centres or water surface. The spatial autocorrelation analysis of agriculture share returned a Moran's I value of 0.59 indicating relatively high spatial concentration of hexagons.

The SDI, calculated as a proxy indicator for agrobiodiversity, showed low positive spatial autocorrelation (Moran's $I=0.37)$. Areas with a high share of organic agriculture, however, showed no explicitly higher values for the SDI.

The share of landscape elements was generally low in relation to the total agricultural area (between 0-1\% for 73\% of the hexagons) due to the chosen landscape scale. However, they perform a number of functions, such as serving as windbreaks, modifying the microclimate and assisting in soil retention and water purification (Stoate et al. 2009).
They also enhance landscape diversity and connectivity, are explicitly acknowledged as important cultural features and have recreational, aesthetic and heritage value (van der Zanden et al. 2016).

\section{Management (Fig. 5)}

About $8 \%$ of hexagons showed values of more than a $60 \%$ share of organic agriculture with high spatial autocorrelation (Moran's $I=0.56$ ). Best (2006) states that farmers' decision to switch to organic management is dependent on multiple factors, but might include socialisation factors, such as neighbours' perceptions and social connectivity. The decision to switch is also influenced by higher uncertainties in yields leading to a fear of lower income and dependence on subsidies (Best 2006).

Most of the agriculturally used areas were characterised by a high share of cropland (53\% of hexagons show values $>80 \%$ cropland share), and cells with a low share of cropland had low soil quality. In contrast, the maize share was below $20 \%$ in 1,955 of 2,761 cells $(71 \%)$, with low spatial autocorrelation (Moran's $I=0.30$ ).

Brandenburg's mean SQR ranges between 37 and 79 which indicates generally rather low soil quality and thus yield potential. Mean soil quality shows low values of spatial autocorrelation (Moran's $I=0.33$ ).

To identify types of agricultural landscapes and cover systematic patterns, reduction of dimensionality was necessary and subsequently implemented as the two-step cluster analysis.

\section{Types of Agricultural Landscapes and Spatial Patterns}

In this section we answer RQ2, identifying types of agricultural landscapes and their spatial concentrations. The twostep clustering analysis returned the most optimal results with a cluster number of six, with a relatively low BIC value of 7894.076 and the highest distance measure of 1.546 (Table 4 Appendix). The silhouette measure of cluster cohesion and separation indicates a fair quality $(0.3)$ of the resulting number of six clusters. Based on the cluster analysis, we identified six different types of agricultural landscapes in Brandenburg: peri-urban, high fragmentation, low fragmentation, high intensity, low intensity and organic production described in more detail in Fig. 6.

Median values of clusters are summarized in Table 2 and Fig. 7:

The map in Fig. 8 shows the spatial distribution of clusters in Brandenburg. For the join count, results with significance level $p>0.01$, and thus cells with only one or two total neighbouring hexagons, were excluded. We identified a high positive spatial autocorrelation for the high intensity 


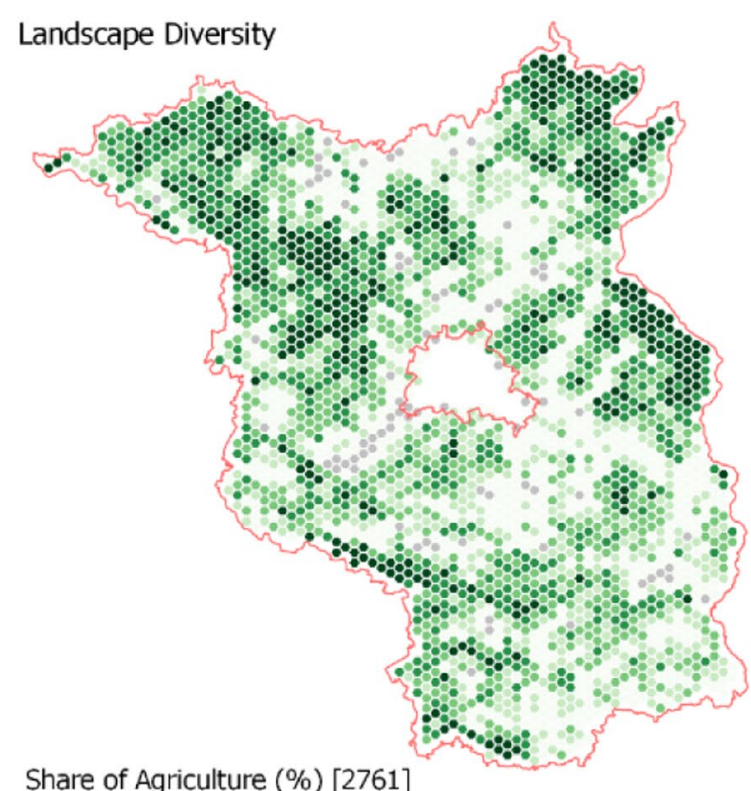

Share of Agriculture (\%) [2761]

$$
0-20 \text { [688] }
$$

$>20-40[523]$

$>40-60[600]$

$>60-80[601]$

$>80-100$ [349]

No Agriculture [75]

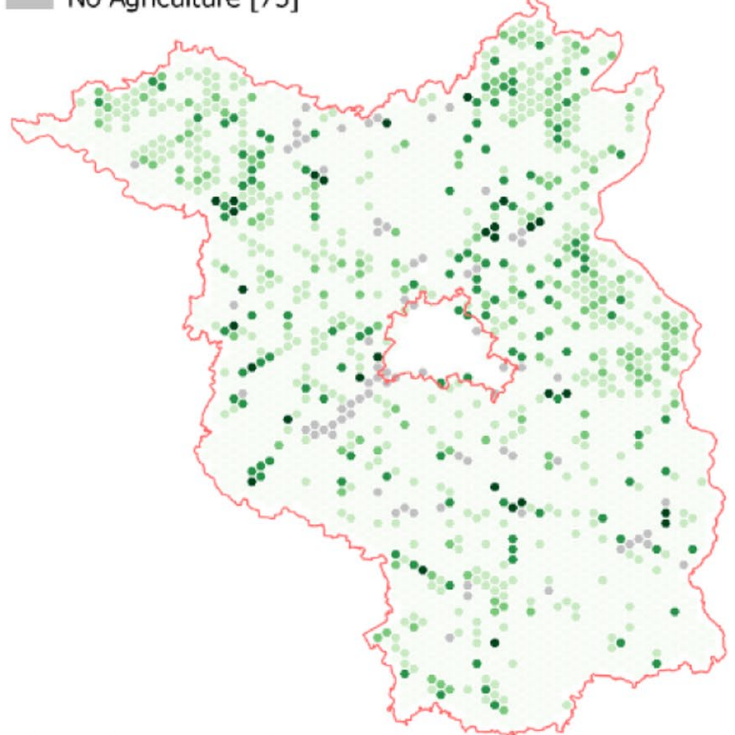

Share of Landscape Elements (\%o)

$$
0-1
$$

$>1-5$

$>5-10$

$>10-50$

$>50-1000$

No Agriculture [75]
Shannon Diversity Index [2761]

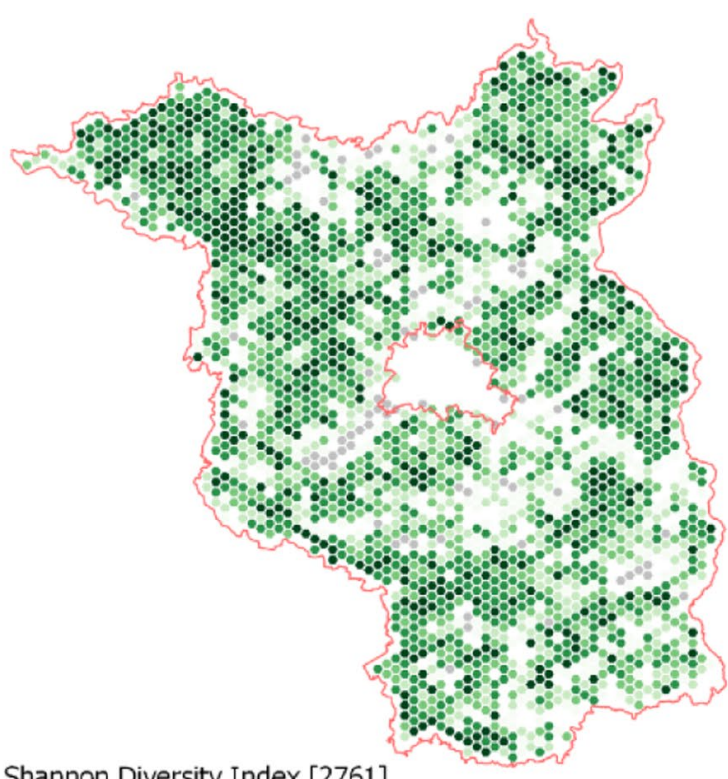

$0-0,33$ [316]

$>0,33-0,87$ [413]

$>0,87-1,26[533]$

$>1,26-1,61$ [790]

$>1,61-2,16$ [437]

No Agriculture [75]

Fig. 4 Maps for landscape diversity indicators including share of agriculture (\% of total area), Shannon Diversity Index and Share of Landscape Elements (\% of total UAA) 


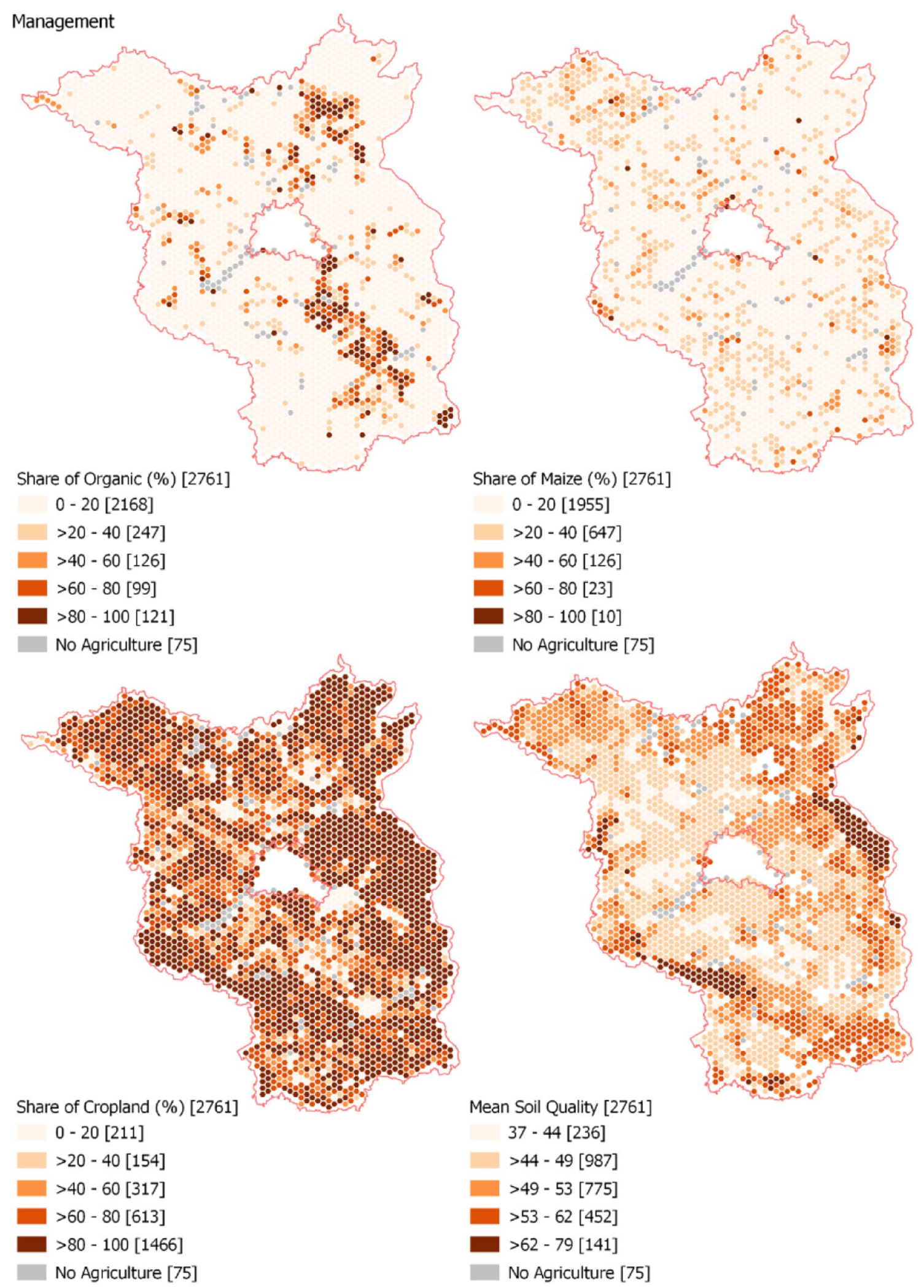

Fig. 5 Maps for Management indicators inlcuding share of organic, share of maize, share of cropland (\% of total UAA) and mean soil quality (points) 


\begin{tabular}{|c|c|c|c|c|}
\hline Sample Image & $\#$ & Name & $\%$ & Description \\
\hline & 1 & Peri-Urban & 5.8 & $\begin{array}{l}\text { Characterised primarily by a high mean number of buildings } \\
(3,206) \text {, the lowest mean share of agricultural area }(24.5 \%) \text { and a } \\
\text { relatively low edge density (mean: } 5.0 \mathrm{~km} / 10 \mathrm{~km} 2) \text {. The lowest } \\
\text { average median plot size ( } 3.0 \text { ha) and soil quality }(49.4) \text { in this } \\
\text { cluster were smaller than in other clusters, as noted by } \\
\text { Weissteiner et al. (2016). The shares of maize and cropland also } \\
\text { tended to be lower than in the other clusters. }\end{array}$ \\
\hline & 2 & $\begin{array}{l}\text { High } \\
\text { Fragmen- } \\
\text { tation }\end{array}$ & 31.6 & $\begin{array}{l}\text { High fragmentation and a high mean of agriculture share }(66.0 \%) \text {. } \\
\text { This goes along with a high share of cropland }(83.7 \%) \text { and maize } \\
(18.4 \%) \text {. }\end{array}$ \\
\hline & 3 & $\begin{array}{l}\text { Low } \\
\text { Fragmen- } \\
\text { tation }\end{array}$ & 22.4 & $\begin{array}{l}\text { Characterised by low fragmentation of the agricultural landscape, } \\
\text { a low mean agriculture share ( } 25.5 \%) \text { but a high share of cropland, } \\
\text { relatively high soil quality and low edge density. The landscape in } \\
\text { this cluster was not dominated by agriculture, but rather other } \\
\text { types of land cover, such as water or forest. }\end{array}$ \\
\hline & 4 & $\begin{array}{l}\text { High } \\
\text { Intensity }\end{array}$ & 8.9 & $\begin{array}{l}\text { Showed the highest mean agriculture share }(66.3 \%) \text {, high-quality } \\
\text { soil }(62.8) \text {, larger mean plot sizes ( } 11.2 \text { ha) with large shares of } \\
\text { cropland }(93.7 \%) \text { and maize }(20.5 \%) .\end{array}$ \\
\hline & 5 & $\begin{array}{l}\text { Low } \\
\text { Intensity }\end{array}$ & 15.6 & $\begin{array}{l}\text { Mainly included grasslands, with a mean agriculture share of } \\
44.5 \% \text {, and had a comparably low mean soil quality }(47.2) \text { and a } \\
\text { low share of cropland ( } 35.7 \%) \text {. In contrast to other clusters } \\
\text { (except Cluster } 6 \text { ), the mean organic share in this cluster was } \\
\text { relatively high (12.9\%). }\end{array}$ \\
\hline & 6 & $\begin{array}{l}\text { Organic } \\
\text { Produc- } \\
\text { tion }\end{array}$ & 11.2 & $\begin{array}{l}\text { Represents organic farming, and was characterised by a low share } \\
\text { of cropland and maize, smaller median plot sizes ( } 3.2 \text { ha) and a } \\
\text { mean agricultural share of } 32.5 \% \text {. }\end{array}$ \\
\hline $\begin{array}{l}\square \text { Grassland } \\
\square \text { Cropland } \\
\text { Google Satellite }\end{array}$ & \multicolumn{4}{|c|}{$\begin{array}{l}\text { Data Sources: } \\
\text { IACS } 2018 \\
\text { Google Satellite }\end{array}$} \\
\hline
\end{tabular}

Fig. 6 Description of agricultural landscape types derived from two-step cluster analysis 
Table 2 Centroid of clusters with the lowest (italic) and highest (bold) values

\begin{tabular}{|c|c|c|c|c|c|c|c|}
\hline \multirow[b]{2}{*}{ Cluster } & \multicolumn{7}{|c|}{ Cluster centroid } \\
\hline & Soil Quality & $\begin{array}{l}\text { Number of } \\
\text { Buildings }\end{array}$ & $\begin{array}{l}\text { Edge Density } \\
\left(\mathrm{km} 10 \mathrm{~km}^{2}\right)\end{array}$ & $\begin{array}{l}\text { Median Plot } \\
\text { Size (ha) }\end{array}$ & $\begin{array}{l}\text { Organic } \\
\text { Share (\%) }\end{array}$ & Maize Share (\%) & $\begin{array}{l}\text { Cropland } \\
\text { Share (\%) }\end{array}$ \\
\hline 1-Peri-urban & 49.4 & 3206.2 & 5.0 & 3.0 & 7.6 & 10.1 & 68.9 \\
\hline 2-High fragmentation & 49.4 & 194.7 & 10.4 & 4.4 & 5.1 & 18.4 & 83.7 \\
\hline 3-Low fragmentation & 51.3 & 197.4 & 4.1 & 3.5 & 5.3 & 19.3 & 86.7 \\
\hline 4-High intensity & 62.8 & 173.9 & 7.9 & 11.2 & 3.2 & 20.5 & 93.7 \\
\hline 5-Low intensity & 47.2 & 207.8 & 8.3 & 4.5 & 12.9 & 7.2 & 35.7 \\
\hline 6-Organic production & 50.4 & 244.6 & 6.3 & 3.2 & 68.9 & 4.8 & 72.1 \\
\hline Combined & 50.8 & 374.8 & 7.7 & 4.6 & 13.5 & 15.1 & 75.6 \\
\hline
\end{tabular}

$(N=98)$ and organic production $(N=95)$ clusters. That is, one agricultural landscape type was likely located next to another agricultural landscape of the same type. The spatial clustering of high-intensity agriculture that we found in our results may be attributed to the underlying spatial clustering of high soil quality.

We found that hexagons with a high percentage of organic farming had lower median plot sizes (cluster 6, Fig. 7), which is in line with the studies of Best (2006) and Caporali et al. (2003). As shown by the study of Bichler and Häring (2003), land with high shares of organic agriculture tends to show higher shares of grassland and lower shares of maize (Fig. 7), especially in Brandenburg where there is a low livestock density. Edge density tends to be higher in areas with a high share of organic farming and a low share of maize. In contrast to other studies, we could not find significantly higher soil qualities in areas under organic production; however, agglomeration effects of organic farming have been noted (Schmidtner et al. 2012). One reason for this finding could be that organic agriculture is possible even in close proximity to nature preserves, which cover larger coherent areas in Brandenburg (Venghaus and Acosta 2018). The low fragmentation $(N=34)$ and low intensity $(N=43)$ clusters did not show a high degree of spatial autocorrelation and were distributed across the state. The peri-urban $(N=54)$ and high fragmentation $(N=71)$ clusters showed medium spatial autocorrelation and seemed randomly spatially distributed over the state, whereby the peri-urban cells were concentrated around Berlin.

The increase of maize cultivation in Brandenburg in recent years has led to areas with larger plot sizes, hence the lower edge densities and potentially intensive management (represented by clusters 3 and 4, N=808 which accounted for $30 \%$ of all hexagons). Lüker-Jans et al. (2016) emphasise that intensive land use is connected to landscapes with rather favourable site conditions for arable cultivation such as relatively flat and fertile land', which corresponds with our findings, particularly for cluster 3 low fragmentation and cluster 4 high intensity. Consistent with Lüker-Jans et al.
(2016), using k-means clustering, we identified similar agricultural types based on cropland share, with maize as a focal crop. However, in contrast to our hexagons, which provided a smooth, homogeneous surface that enabled unambiguous identification of neighbourhoods for the study area, LükerJans et al. (2016) analysed metrics on a municipal level, which resulted in a higher variance in shape and size than grid-based analysis.

\section{General Discussions}

Other studies which identify landscape types consider similar indicators such as plot size, share of cropland, built-up or linear landscape elements (Levers et al. 2018; Tieskens et al. 2017; van der Zanden et al. 2016). In relation to the European archetypes by Levers et al. (2018), our identified types are in line with the intensity classifications for Brandenburg (i.e. large share of cropland or as landscape mosaic). However, our clusters considered additional, region-specific plotbased information with a focus on agricultural landscape structure, diversity and management characteristics. Similar to van der Zanden et al. (2016), Tieskens et al. (2017), who also take into account landscape composition, structure and management indicators but on a European level, our types range from small to large farming scale as indicated by median plot sizes, and can be further differentiated by edge density (potential linear elements) and land management intensity (approximated by the share of cropland and maize). Several studies showed that Brandenburg is characterised by agriculture under medium to large scale arable land (Andersen et al. 2013; Levers et al. 2018; van der Zanden et al. 2016). In addition to the identification landscape types, our study analysed the spatial patterns of characteristics and types showing that particularly high intensity and organic farming tend to be spatially concentrated.

Our results complement and broaden information about agricultural landscapes, such as the agro-ecological zones of Brandenburg (Landbaugebiete), that have been given a suitability rating for crop production potentials (Ackerzahl; 


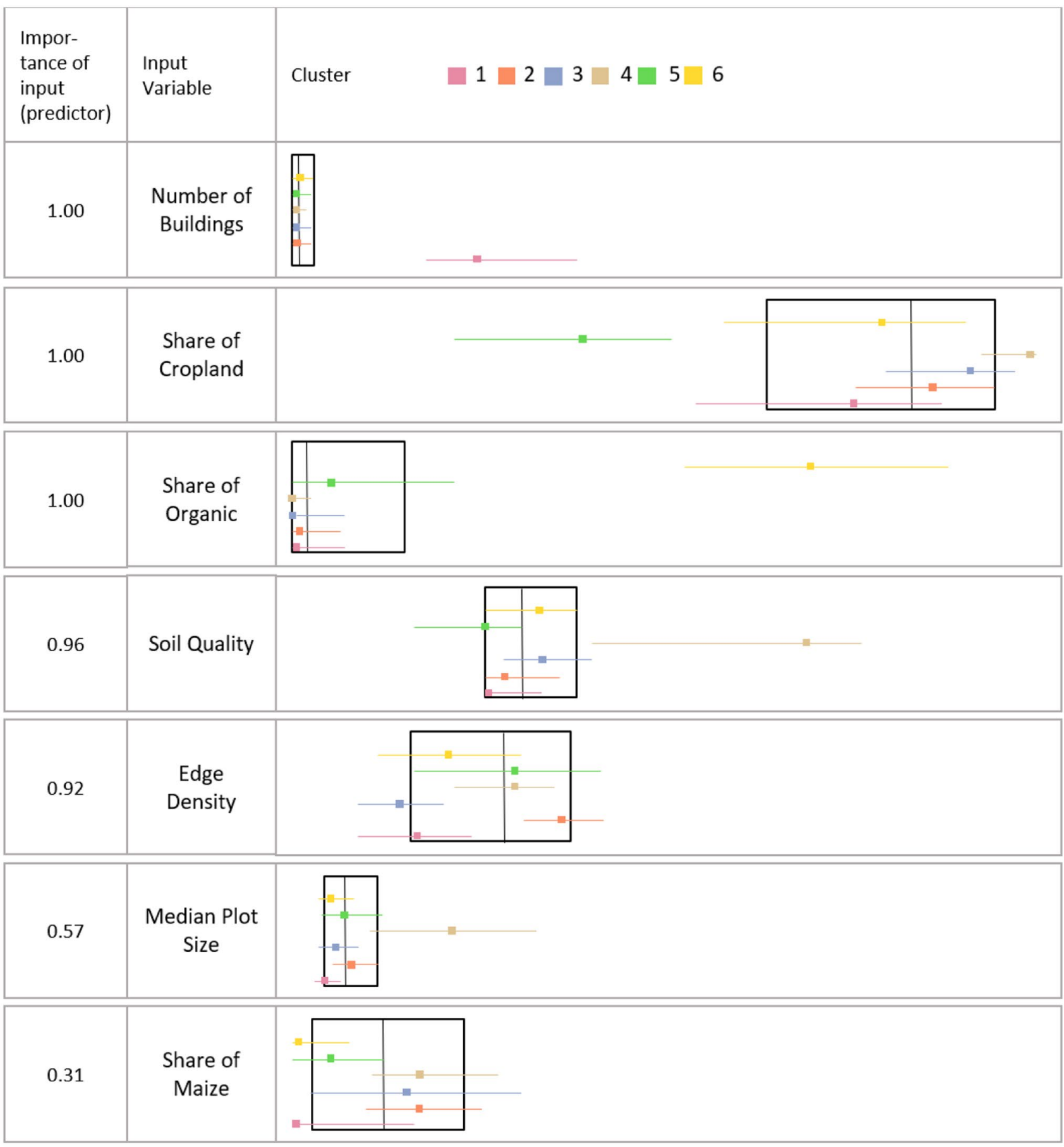

Fig. 7 Comparison of input variables' value of importance and statistic values for clusters; colorbars represent clusters (1-6) with median and $25 \%$ and $75 \%$ quantile, white boxes represent the combined values showing median, $25 \%$ and $75 \%$ quantile

Landesamt für Ländliche Entwicklung, Landwirtschaft und Flurneuordnung 2016) and the maps available in the Thünen Atlas, including the distribution of crop types or grassland on a municipal scale (Thünen Institut, 2014). Using a plotbased analysis, we add new information to the existing data regarding composition, configuration, diversity, and management, including intensity, which may become relevant also from a perspective of resilience and climate smartness of landscapes. Earlier typologies of Brandenburg's agriculture have been based mainly on farmers' decisions and referenced renewable energy production (Venghaus and Acosta 2018). These authors considered farmers as decision 


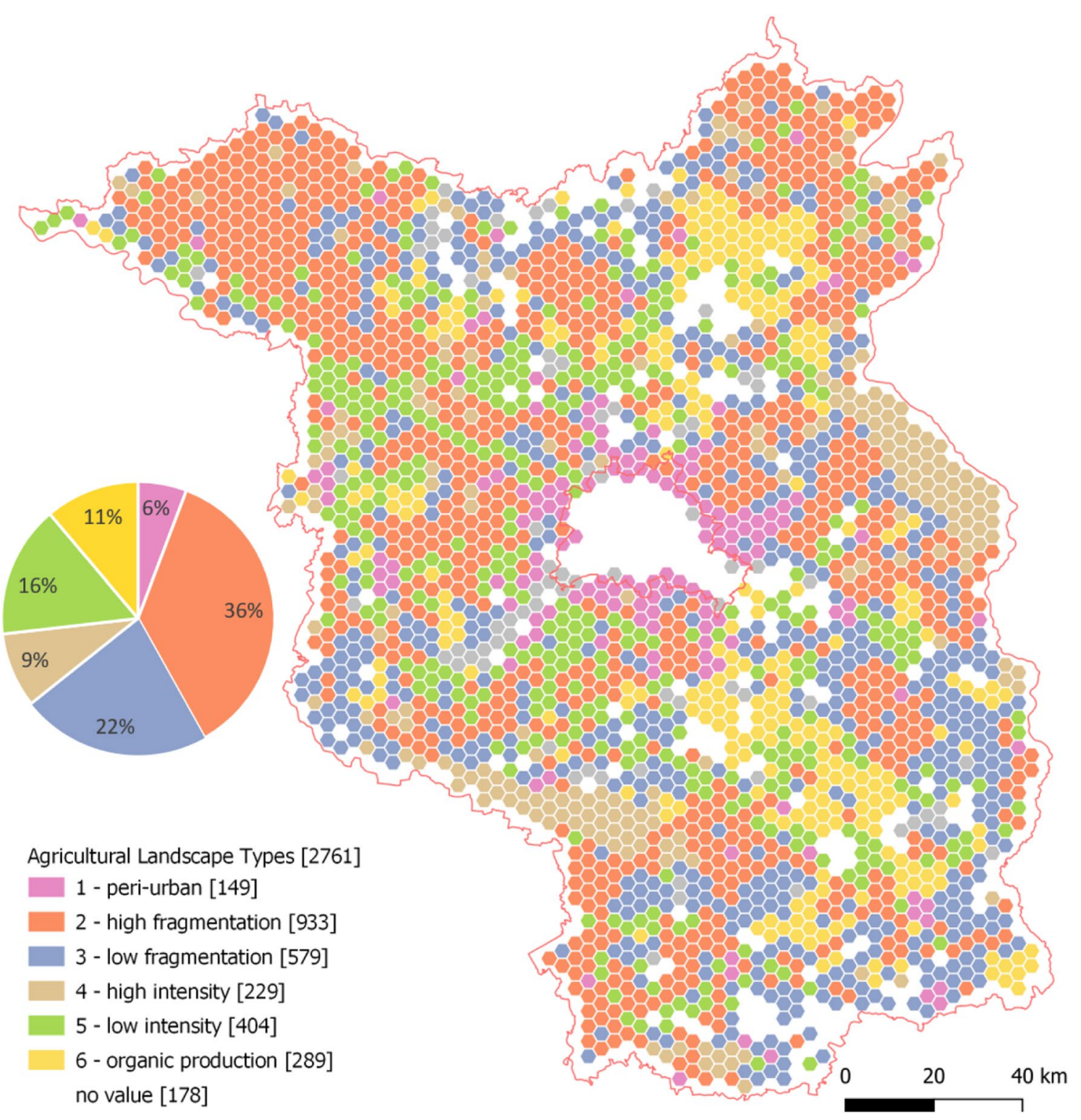

Fig. 8 Map of agricultural landscape types in Brandenburg, Germany in 2018 with exemplary satellite imagery for each type (Google)

makers as the designers of agricultural landscapes; however, the explicit landscape composition scale as we do here was not considered explicitly. In this study, we used different metrics as inputs for typologising agriculture on a landscape level and thus complement the results of Uthes et al. (2020) and Venghaus and Acosta (2018), who focused their analysis on the farm level.

Our approach innovatively integrates different metrics into a new land-use typology, which we consider an improvement over the use of single indicators (e.g. soil quality). The newly provided information improves the understanding of the agricultural landscape structure in Brandenburg and helps identifying regions specified support measures may be required. Additionally, the region-specific types can be used for monitoring changes over time or assessing changes after e.g. policy measures have been implemented from an outcome-based perspective. Resulting changes may for instance include the frequency and spatial distribution of identified types, but may also generate new types that are not included in the six used in this study.

Agricultural production in particular creates pressure on the environment whereby appropriate farming systems help preserve landscapes and habitats (Lütz and Felici 2009). From the European policy perspective, the supply of ecosystem services and biodiversity conservation within farmland is fostered by the EU Biodiversity Strategy to 2020 and within the CAP's greening measures (Weissteiner et al. 2016, p. 317). Typologising the agricultural landscape in 
Brandenburg allows for the comprehensive assessment of the potential prioritization of areas for the supply of environmental measures, such as the implementation of green infrastructures to support landscape diversity and connectivity supported by multifunctional agriculture (Oberlack et al. 2019). Through typologising agricultural landscapes, along with estimates of the provision of ESS by type offers a step forward towards landscape-type functioning assessment. Exemplarily, Type 3 (low fragmentation) and Type 4 (high intensity) could indicate low habitat diversity due to large median plot sizes, low edge density and a high share of cropland and maize. Contrary, Type 2 (high fragmentation) and Type 5 (low intensity) indicate a potentially higher habitat diversity through a comparably low share of cropland and agriculture in general as well as through high edge densities. At the same time, in agricultural landscapes with a high share of organic agriculture (particularly Type 6) the farming systems are potentially offering enhanced ESS, e.g. biodiversity, soil quality or pollination services, and at the same time show low environmental impacts of agricultural production (Bavec and Bavec 2015). Based on this approach, likewise, typologising could be combined with climate smartness assessments, and help policy makers in defining and evaluating respective agricultural landscape feature goals.

Although our results are shown for an exemplary case study of Brandenburg, Germany, the methodology can be applied to other regions where sufficient data is available such as other regions in Germany and the EU. The integration of metrics via cluster analysis may result in different (number of) typologies in other areas, which is, however, one advantage of utilizing small-scale region-specific data rather than generalized types. The landscape focus enhances a more integrated assessment of agricultural landscapes than the focus on pure farm size and farm-based characteristic. Furthermore, a typology based on landscape structure, diversity and management is independent of the area of application and can thus be ubiquitarily applied as a general framework for the characterization of agricultural land.

\section{Limitations and Further Research}

Similar to Lomba et al. (2017), Uthes et al. (2020) and Lüker-Jans et al. (2016), we were able to show the potential of IACS data for analysing agricultural land use. Future backing through remote sensing data, such as crop type mapping (Griffiths et al. 2018), crop yield mapping (Lobell et al. 2015) or landscape pattern analysis (Weissteiner et al. 2016), would increase the potential for this approach to be applied to areas in which frequent land-use monitoring is not available. In this study, we did not consider the temporal dimension of land use, e.g. crop rotation and crop diversity over time. Applying our proposed method to different time slices would make it possible to address changes in the set of indicators and the resulting clustering. This would reveal processes that occur in the agricultural landscape and could help identify how changes in boundary conditions would impact the composition of a landscape. In Brandenburg, two prominent examples of such processes are the increase of maize in the crop portfolio and the construction of biogas plants in direct response to implementation of the Act on Granting Priority to Renewable Energy Sources in 2000 (Federal Environmental Ministry 2000). Such developments would be revealed by an analysis with multiple time periods of IACS data. Furthermore, our results do not represent a full set of potential agricultural landscape types, e.g. across the whole EU under different landscape structure, diversity and farmland management characteristics. We argue, however, that the methodological approach is highly transferable to other regions in the EU, where IACS data are available; missing soil quality assessments could for instance be replaced by increasingly available remote sensing data.

A common problem in ecological analyses of spatial indicators is the spatial scale and the unit of analysis known as the Modifiable Area Unit Problem (MAUP) (Wu 2004) which is not quantitatively analysed within this study. Scale dependence (of metrics and number of clusters) could be addressed by performing a sensitivity analysis of e.g. changing grid cell size in future studies. In earlier studies, however, landscape metrics have proven to be a suitable tool for landscape analysis, even though there are limitations when it comes to up- and down-scaling of the generated results (Schlesinger and Drescher 2018).

\section{Conclusions}

This paper focuses on the methodological suitability of standard and landscape metrics as an input for cluster analysis within a hexagonal grid. One of the advantages of using IACS data is the potential to transfer the approach to other study regions in which similar monitoring data are available.

Our findings reveal six different types of agricultural landscapes and their respective spatial patterns. We conclude that Brandenburg is characterised by highly fragmented agriculture and a high degree of spatial clustering of intensive agriculture and organic production. The chosen landscape metrics derived from IACS data have proven to be adequate for improving the understanding of agricultural landscapes. The approach could potentially be applied for measuring agricultural landscape structure and diversity in terms of plot composition and configuration at the EU level since IACS data are available across the EU. Our paper proposes an approach at the landscape level, which, according to Thomson et al. (2019), provides a fundamental connection between the diverse array of relevant 


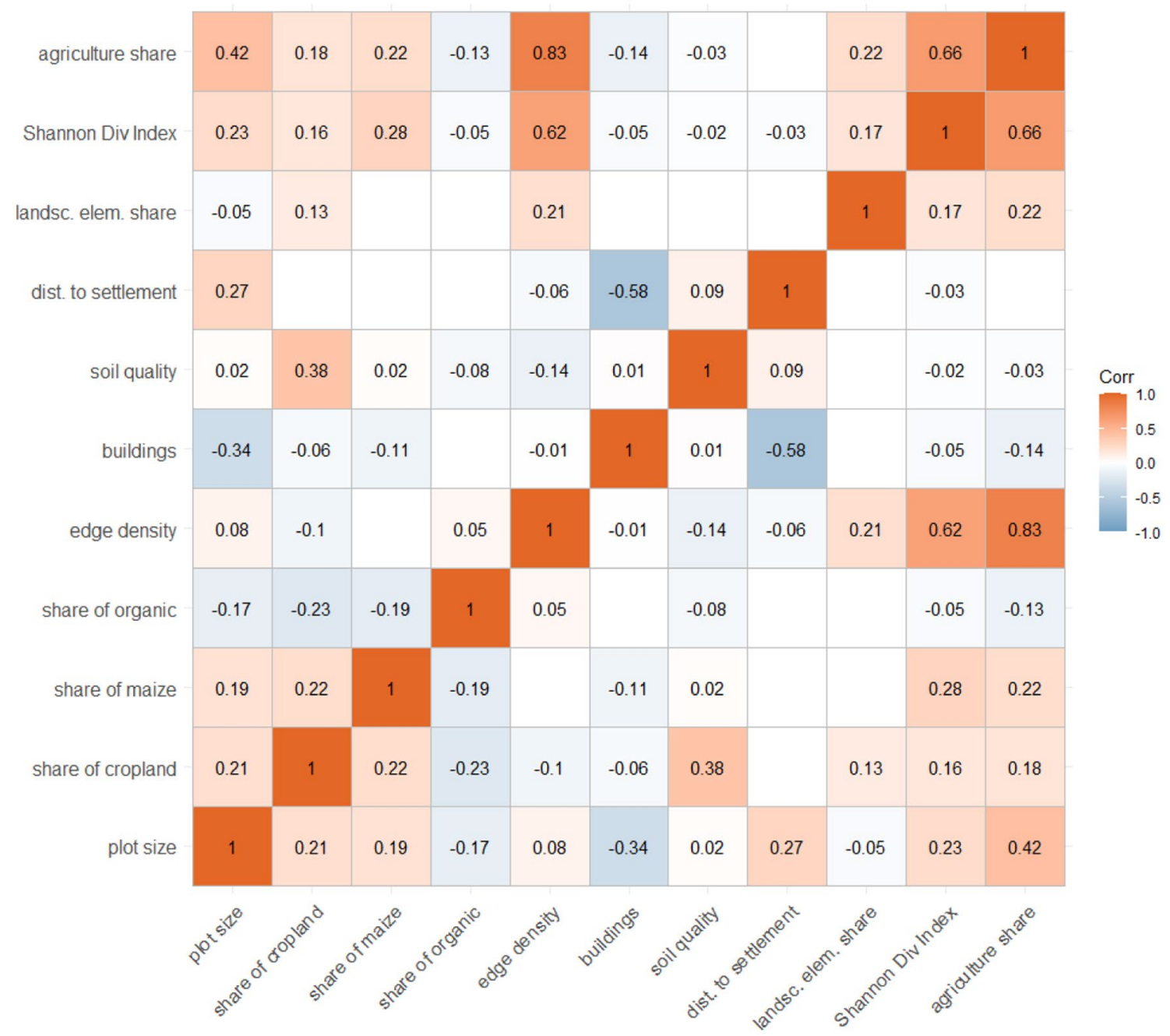

Fig. 9 Spearman correlation coefficient matrix of indicators (blank $=$ not significant)

socio-economic and biophysical conditions and processes and can inform particularly regional decision-making.

In addition to performing spatio-temporal analysis, future work should address the relations among different types of agricultural landscapes and land price development, ownership patterns and trade-offs, for example between food and energy production, particularly on different units of analysis in regard to decision-making units.

\section{Availability of data and material (data transparency)}

Not applicable.

\section{Code availability (software application or custom code)}

Not applicable.

\section{Appendix}

See Fig. 9 and Tables 3, 4

Acknowledgement This work was supported by the Deutsche Forschungsgemeinschaft as part of Research Unit 2569, 'Agricultural Land Markets-Efficiency and Regulation'. We thank the Landesamt für Ländliche Entwicklung, Landwirtschaft und Flurneuordnung (LELF) and the Minsterium für Landwirtschaft, Umwelt und Klimaschutz (MLUL) for providing the IACS data.

Author Contributions Conceptualization: Saskia Wolff, Tobia Lakes; Methodology: Saskia Wolff; Formal analysis and investigation: Saskia Wolff; Writing - original draft preparation: Saskia Wolff; Writing review and editing: Tobia Lakes, Silke Hüttel, Claas Nendel; Funding acquisition: Tobia Lakes; Supervision: Tobia Lakes.

Funding Open Access funding enabled and organized by Projekt DEAL. Deutsche Forschungsgemeinschaft as part of Research Unit 2569, 'Agricultural Land Markets-Efficiency and Regulation'. 
Table 3 Total values (all hexagons) for landscape characteristics in Brandenburg, Germany 2018

\begin{tabular}{lrrrr}
\hline Category/indicator & Min & \multicolumn{1}{c}{ Max } & Median & Standard deviation \\
\hline Landscape structure & & & & \\
$\quad$ Plot size (ha) & 0.1 & 46.9 & 3.4 & 4.1 \\
Edge Density (m/10 km $\left.{ }^{2}\right)$ & 4.8 & $28,529.9$ & 7632.4 & 4135.6 \\
$\quad$ Number of buildings & 0.0 & $10,475.0$ & 103.0 & 924.2 \\
$\quad$ Distance to settlements (m) & 23.6 & 8506.6 & 1416.3 & 1130.2 \\
Landscape diversity & & & & \\
$\quad$ Share of agriculture (\%) & 0.0 & 96.4 & 45.34 & 27.4 \\
$\quad$ Shannon Diversity Index & 0.0 & 2.2 & 1.2 & 0.6 \\
$\quad$ Share of landscape elements (\%) & 0.0 & 1000.0 & 0.0 & 35.3 \\
Management & & & & \\
$\quad$ Share of organic agriculture (\%) & 0.0 & 100.0 & 1.8 & 24.0 \\
$\quad$ Share of maize (\%) & 0.0 & 100.0 & 11.0 & 14.7 \\
Share of cropland (\%) & 0.0 & 100.0 & 82.1 & 27.2 \\
$\quad$ Soil quality & 37.0 & 79.0 & 50.0 & 6.1 \\
\hline
\end{tabular}

Table 4 Automatic clustering. Six clusters show a relatively low BIC and high distance measures

\begin{tabular}{lrlll}
\hline $\begin{array}{l}\text { \# Of Clus- } \\
\text { ters }\end{array}$ & BIC & BIC change $^{\mathrm{a}}{ }^{\mathrm{R}}$ & $\begin{array}{l}\text { Relations } \\
\text { of BIC } \\
\text { changes }^{\mathrm{b}}\end{array}$ & $\begin{array}{l}\text { Relations } \\
\text { of distance }_{\text {measures }}{ }^{\mathrm{c}}\end{array}$ \\
\hline 1 & $12,639.288$ & & & \\
2 & $10,915.973$ & -1723.315 & 1.000 & 1.269 \\
3 & 9581.095 & -1334.878 & 0.775 & 1.664 \\
4 & 8822.853 & -758.241 & 0.440 & 1.349 \\
5 & 8289.365 & -533.488 & 0.310 & 1.274 \\
6 & $\mathbf{7 8 9 4 . 0 7 6}$ & $-\mathbf{3 9 5 . 2 8 9}$ & $\mathbf{0 . 2 2 9}$ & $\mathbf{1 . 5 4 6}$ \\
7 & 7677.336 & -216.740 & 0.126 & 1.074 \\
8 & 7483.168 & -194.168 & 0.113 & 1.086 \\
9 & 7313.045 & -170.124 & 0.099 & 1.069 \\
10 & 7160.902 & -152.143 & 0.088 & 1.273 \\
11 & 7065.035 & -95.867 & 0.056 & 1.206 \\
12 & 7004.337 & -60.698 & 0.035 & 1.188 \\
13 & 6970.704 & -33.633 & 0.020 & 1.024 \\
14 & 6940.408 & -30.297 & 0.018 & 1.041 \\
15 & 6915.647 & -24.760 & 0.014 & 1.285 \\
\hline
\end{tabular}

Bold values indicate relatively low BIC and high distance measure resulting from two-step clauster analysis for the number of clusters $=6$.

${ }^{a}$ The changes were based on the previous number of clusters in the table.

${ }^{b}$ The change rates are relative to the change in the two cluster solutions.

${ }^{c}$ The distance measurements are based on comparison of the current number of clusters with the previous number of clusters.

\section{Declarations}

Conflict of interest Not applicable.
Open Access This article is licensed under a Creative Commons Attribution 4.0 International License, which permits use, sharing, adaptation, distribution and reproduction in any medium or format, as long as you give appropriate credit to the original author(s) and the source, provide a link to the Creative Commons licence, and indicate if changes were made. The images or other third party material in this article are included in the article's Creative Commons licence, unless indicated otherwise in a credit line to the material. If material is not included in the article's Creative Commons licence and your intended use is not permitted by statutory regulation or exceeds the permitted use, you will need to obtain permission directly from the copyright holder. To view a copy of this licence, visit http://creativecommons.org/licenses/by/4.0/.

\section{References}

Amt für Statistik Berlin-Brandenburg (2016) Struktur der land- und forstwirtschaftlichen Betriebe, EVAS: 41121. Potsdam. www.stati stik-berlin-brandenburg.de

Andersen PS, Vejre H, Dalgaard T, Brandt J (2013) An indicator-based method for quantifying farm multifunctionality. Ecol Ind 25:166179. https://doi.org/10.1016/j.ecolind.2012.09.025

Bavec M, Bavec F (2015) Impact of organic farming on biodiversity. In: Lo Y-H, Blanco JA, Roy S (eds) Biodiversity in ecosystems: linking structure and function. InTech, London. https://doi.org/ $10.5772 / 58974$

Benton TG, Vickery JA, Wilson JD (2003) Farmland biodiversity: is habitat heterogeneity the key? Trends Ecol Evol 18(4):182-188. https://doi.org/10.1016/S0169-5347(03)00011-9

Best H (2006) Die Umstellung auf ökologische Landwirtschaft als Entscheidungsprozess, 1st edn. VS Verlag für Sozialwissenschaften, GWV Fachverlage GmbH Wiesbaden, Wiesbaden

Bichler B, Häring AM (2003) Die räumliche Verteilung des ökologischen Landbaus in Deutschland und ihre Bestimmungsgründe. https://orgprints.org/5046/1/5046-02OE469-uni-hohenheim2003-raeuml-verteilg.pdf. Accessed 18 Mar 2020

Birch CP, Oom SP, Beecham JA (2007) Rectangular and hexagonal grids used for observation, experiment and simulation in ecology. Ecol Model 206(3-4):347-359. https://doi.org/10.1016/j.ecolm odel.2007.03.041

BMJV (2007) Gesetz zur Schätzung des Landwirtschaftlichen Kulturbodens (Bodenschätzungsgesetz-BodSchätzG). https://www. 
gesetze-im-internet.de/bodsch_tzg_2008/BodSch\%C3\%A4tzG. pdf. Accessed 17 Mar 2020

Bundesanstalt für Geowissenschaften und Rohstoffe (2014) Ackerbauliches Ertragspotential der Böden in Deutschland. https://www. bgr.bund.de/DE/Themen/Boden/Ressourcenbewertung/Ertragspot ential/Ertragspotential_node.html. Accessed 21 Jan 2020

Burchfield EK, Nelson KS, Spangler K (2019) The impact of agricultural landscape diversification on U.S. crop production. Agric Ecosyst Environ 285:106615. https://doi.org/10.1016/j.agee.2019. 106615

Burel F, Baudry J (2005) Habitat quality and connectivity in agricultural landscapes: The role of land use systems at various scales in time. Ecol Ind 5(4):305-313. https://doi.org/10.1016/j.ecolind. 2005.04.002

Caporali F, Mancinelli R, Campiglia E (2003) Indicators of cropping system diversity in organic and conventional farms in central Italy. Int J Agric Sustain 1(1):67-72. https://doi.org/10.3763/ijas.2003. 0107

Chiu T, Fang D, Chen J, Wang Y, Jeris C (2001) A robust and scalable clustering algorithm for mixed type attributes in large database environment. In: Provost F (ed) Proceedings of the seventh ACM SIGKDD international conference on Knowledge discovery and data mining. ACM, Washington, pp 263-268

Crist TO, Peters VE (2014) Landscape and local controls of insect biodiversity in conservation grasslands: implications for the conservation of ecosystem service providers in agricultural environments. Land 3(3):693-718. https://doi.org/10.3390/land3030693

Dengler J (2009) Which function describes the species-area relationship best? A review and empirical evaluation. J Biogeogr 36(4):728-744. https://doi.org/10.1111/j.1365-2699.2008.02038.x

Eisenack K, Villamayor-Tomas S, Epstein G, Kimmich C, Magliocca N, Manuel-Navarrete D, Oberlack C, Roggero M, Sietz D (2019) Design and quality criteria for archetype analysis. Ecol Soc. https://doi.org/10.5751/ES-10855-240306

Erb K-H, Haberl H, Jepsen MR, Kuemmerle T, Lindner M, Müller D, Verburg PH, Reenberg A (2013) A conceptual framework for analysing and measuring land-use intensity. Curr Opin Environ Sustain 5(5):464-470. https://doi.org/10.1016/j.cosust.2013.07.010

Estel S, Kuemmerle T, Levers C, Baumann M, Hostert P (2016) Mapping cropland-use intensity across Europe using MODIS NDVI time series. Environ Res Lett 11(2):24015. https://doi.org/10. 1088/1748-9326/11/2/024015

Fan H, Zipf A, Fu Q, Neis P (2014) Quality assessment for building footprints data on OpenStreetMap. Int J Geogr Inf Sci 28(4):700719. https://doi.org/10.1080/13658816.2013.867495

Federal Environmental Ministry (2000) Act on Granting Priority to Renewable Energy Sources (Renewable Energy Sources Act). https://www.lexadin.nl/wlg/legis/nofr/eur/arch/ger/resact.pdf. Accessed 17 Mar 2020

FNR (2013) Biogas an introduction. Fachagentur Nachwachsende Rohstoffe e. V. https://mediathek.fnr.de/media/downloadable/ files/samples/b/r/brosch.biogas-2013-en-web-pdf.pdf. Accessed 23 Mar 2020

Gabriel D, Sait SM, Hodgson JA, Schmutz U, Kunin WE, Benton TG (2010) Scale matters: The impact of organic farming on biodiversity at different spatial scales. Ecol Lett 13(7):858-869. https:// doi.org/10.1111/j.1461-0248.2010.01481.x

Griffith JA, Martinko EA, Price KP (2000) Landscape structure analysis of Kansas at three scales. Landsc Urban Plan 52(1):45-61. https://doi.org/10.1016/S0169-2046(00)00112-2

Griffiths P, Nendel C, Hostert P (2018) National-scale crop- and land-cover map of Germany (2016) based on imagery acquired by Sentinel-2A MSI and Landsat-8 OLI, supplement to: Griffiths, Patrick; Nendel, Claas; Hostert, Patrick (2019): intraannual reflectance composites from Sentinel-2 and Landsat for national-scale crop and land cover mapping. Remote Sens Environ 220:135-151. https://doi.org/10.1594/PANGAEA.893195

Grundmann P, Klauss H (2014) The impact of global trends on bioenergy production, food supply and global warming potential: an impact assessment of land-use changes in four regions in Germany using linear programming. J Land Use Sci 9(1):34-58. https://doi. org/10.1080/1747423X.2012.719935

Gutzler C, Helming K, Balla D, Dannowski R, Deumlich D, Glemnitz M, Knierim A, Mirschel W, Nendel C, Paul C, Sieber S, Stachow U, Starick A, Wieland R, Wurbs A, Zander P (2015) Agricultural land use changes: a scenario-based sustainability impact assessment for Brandenburg, Germany. Ecol Indic 48:505-517. https:// doi.org/10.1016/j.ecolind.2014.09.004

Hartvigsen M (2014) Land reform and land fragmentation in Central and Eastern Europe. Land Use Policy 36:330-341. https://doi.org/ 10.1016/j.landusepol.2013.08.016

Harvolk S, Kornatz P, Otte A, Simmering D (2014) Using existing landscape data to assess the ecological potential of Miscanthus cultivation in a marginal landscape. GCB Bioenergy 6(3):227241. https://doi.org/10.1111/gcbb.12078

Hüttel S, Wildermann L, Croonenbroeck C (2016) How do institutional market players matter in farmland pricing? Land Use Policy 59:154-167. https://doi.org/10.1016/j.landusepol.2016.08.021

Jokar Arsanjani J, Zipf A, Mooney P, Helbich M (eds) (2015) Lecture notes in geoinformation and cartography. Openstreetmap in GIScience: experiences, research, and applications. Springer International Publishing, Berlin. https://doi.org/10.1007/ 978-3-319-14280-7

Lambin E, Rounsevell M, Geist H (2000) Are agricultural land-use models able to predict changes in land-use intensity? Agric Ecosyst Environ 82(1):321-331. https://doi.org/10.1016/S01678809(00)00235-8

Landesamt für Ländliche Entwicklung, Landwirtschaft und Flurneuordnung (2016) Datensammlung für die betriebswirtschaftliche Bewertung landwirtschaftlicher Produktionsverfahren im Land Brandenburg. https://lelf.brandenburg.de/media_fast/4055/Daten sammlung\%202016_web.pdf. Accessed 23 Jan 2020

Lausch A, Herzog F (2002) Applicability of landscape metrics for the monitoring of landscape change: issues of scale, resolution and interpretability. Ecol Ind 2(1):3-15. https://doi.org/10.1016/ S1470-160X(02)00053-5

Levers C, Müller D, Erb K, Haberl H, Jepsen MR, Metzger MJ, Meyfroidt P, Plieninger T, Plutzar C, Stürck J, Verburg PH, Verkerk PJ, Kuemmerle T (2018) Archetypical patterns and trajectories of land systems in Europe. Reg Environ Change 18(3):715-732. https://doi.org/10.1007/s10113-015-0907-x

Lobell DB, Thau D, Seifert C, Engle E, Little B (2015) A scalable satellite-based crop yield mapper. Remote Sens Environ 164:324 333. https://doi.org/10.1016/j.rse.2015.04.021(RemoteSensingof Environment, 164,324-333)

Lomba A, Strohbach M, Jerrentrup JS, Dauber J, Klimek S, McCracken DI (2017) Making the best of both worlds: can high-resolution agricultural administrative data support the assessment of High Nature Value farmlands across Europe? Ecol Ind 72:118-130. https://doi.org/10.1016/j.ecolind.2016.08.008

Lomba A, Moreira F, Klimek S, Jongman RHG, Sullivan C, Moran J, Poux X, Honrado JP, Pinto-Correia T, Plieninger T, McCracken DI (2020) Back to the future: rethinking socioecological systems underlying high nature value farmlands. Front Ecol Environ 18(1):36-42. https://doi.org/10.1002/fee.2116

Lüker-Jans N, Simmering D, Otte A (2016) Analysing data of the integrated administration and control system (IACS) to detect patterns of agricultural land-use change at municipality level. Lands Online 48:1-24. https://doi.org/10.3097/LO.201648 
Lütz M, Felici F (2009) Indicators to identify the agricultural pressures on environmental functions and their use in the development of agri-environmental measures. Reg Environ Change 9(3):181-196. https://doi.org/10.1007/s10113-008-0061-9

Matzdorf B, Kaiser T, Rohner M-S (2008) Developing biodiversity indicator to design efficient agri-environmental schemes for extensively used grassland. Ecol Ind 8(3):256-269. https://doi.org/10. 1016/j.ecolind.2007.02.002

MLUK (2019) Massnahmeprogramm Oekologische Produktion. https://mluk.brandenburg.de/sixcms/media.php/9/Massnahmep rogramm_Oekologische_Produktion.pdf. Accessed 24 Jan 2020

Monteleone M, Cammerino ARB, Libutti A (2018) Agricultural "greening" and cropland diversification trends: potential contribution of agroenergy crops in Capitanata (South Italy). Land Use Policy 70:591-600. https://doi.org/10.1016/j.landusepol.2017. 10.038

Moran PAP (1950) Notes on continuous stochastic phenomena. Biometrika 37(1/2):17. https://doi.org/10.2307/2332142

Mueller L, Schindler U, Behrendt A, Eulenstein F, Dannowski R (2007) The Muencheberg Soil Quality Rating. http://www.zalf.de/de/ forschung_lehre/publikationen/Documents/Publikation_Muell er_L/field_mueller.pdf. Accessed 21 Jan 2020

Oberlack C, Sietz D, Bürgi Bonanomi E, de Bremond A, Dell'Angelo J, Eisenack K, Ellis EC, Epstein G, Giger M, Heinimann A, Kimmich C, Kok MTJ, Manuel-Navarrete D, Messerli P, Meyfroidt P, Václavík T, Villamayor-Tomas S (2019) Archetype analysis in sustainability research: meanings, motivations, and evidence-based policy making. Ecol Soc. https://doi.org/10.5751/ES-10747-240226

Piorr A, Zasada I, Doernberg A, Zoll F, Ramme W (2018) Research for AGRI Committee: urban and peri-urban agriculture in the EU : study requested by the AGRI committee. Eur Union. https://doi. org/10.2861/46620

Plant RE (2012) Spatial data analysis in ecology and agriculture using R. CRC Press, Boston

Rega C, Short C, Pérez-Soba M, Luisa Paracchini M (2020) A classification of European agricultural land using an energy-based intensity indicator and detailed crop description. Landsc Urban Plan 198:103793. https://doi.org/10.1016/j.landurbplan.2020.103793

Ritter M, Hüttel S, Walter M, Odening M (2015) Der Einfluss von Windkraftanlagen auf landwirtschaftliche Bodenpreise. Berichte über Landwirtschaft Zeitschrift für Agrarpolitik und Landwirtschaft. https://doi.org/10.12767/buel.v93i3.83

Schaller L, Targetti S, Villanueva AJ, Zasada I, Kantelhardt J, Arriaza M, Bal T, Fedrigotti VB, Giray FH, Häfner K, Majewski E, MalakRawlikowska A, Nikolov D, Paoli J-C, Piorr A, Rodríguez-Entrena M, Ungaro F, van Verburg PH, van Zanten B, Viaggi GR (2018) Agricultural landscapes, ecosystem services and regional competitiveness: assessing drivers and mechanisms in nine European case study areas. Land Use Policy 76:735-745. https://doi.org/10.1016/j. landusepol.2018.03.001

Scheffer F, Schachtschabel P, Blume H-P, Brümmer GW, Horn R, Kandeler E, Kögel-Knabner I, Kretzschmar R, Stahr K, Thiele-Bruhn S, Welp G, Wilke B-M (2010) Lehrbuch der Bodenkunde (16. Auflage). Spektrum Akademischer Verlag, Heidelberg. https://doi. org/10.1007/978-3-8274-2251-4

Schindler S, Poirazidis K, Wrbka T (2008) Towards a core set of landscape metrics for biodiversity assessments: a case study from Dadia National Park, Greece. Ecol Indic 8(5):502-514. https://doi.org/10. 1016/j.ecolind.2007.06.001

Schlesinger J, Drescher AW (2018) Agricultural land use and the urbanrural gradient: an analysis of landscape metrics in Moshi, Tanzania. Afr Geogr Rev 37(1):14-29. https://doi.org/10.1080/19376812. 2016.1229202

Schmidtner E, Lippert C, Engler B, Häring AM, Aurbacher J, Dabbert S (2012) Spatial distribution of organic farming in Germany: does neighbourhood matter? Eur Rev Agric Econ 39(4):661-683. https:// doi.org/10.1093/erae/jbr047

Shriar AJ (2000) Agricultural intensity and its measurement in frontier regions. Agrofor Syst 49(3):301-318. https://doi.org/10.1023/A: 1006316131781

Statistisches Bundesamt (2019) Land und Forstwirtschaft, Fischerei: Viehbestand, Article Artikelnummer 2030410185324. https:// www.destatis.de/DE/Themen/Branchen-Unternehmen/Landwirtsc haft-Forstwirtschaft-Fischerei/Tiere-Tierische-Erzeugung/Publikatio nen/Downloads-Tiere-und-tierische-Erzeugung/viehbestand-20304 10185324.pdf?_blob=publicationFile\&v=5. Accessed 9 Mar 2020

Stoate C, Báldi A, Beja P, Boatman ND, Herzon I, van Doorn A, de Snoo GR, Rakosy L, Ramwell C (2009) Ecological impacts of early 21st century agricultural change in Europe: a review. J Environ Manag 91(1):22-46. https://doi.org/10.1016/j.jenvman.2009.07.005

Strohbach MW, Kohler ML, Dauber J, Klimek S (2015) High nature value farming: from indication to conservation. Ecol Ind 57:557-563. https://doi.org/10.1016/j.ecolind.2015.05.021

Su S, Jiang Z, Zhang Q, Zhang Y (2011) Transformation of agricultural landscapes under rapid urbanization: a threat to sustainability in Hang-Jia-Hu region, China. Appl Geogrs 31(2):439-449. https:// doi.org/10.1016/j.apgeog.2010.10.008

Su S, Hu Y, Luo F, Mai G, Wang Y (2014) Farmland fragmentation due to anthropogenic activity in rapidly developing region. Agric Syst 131:87-93. https://doi.org/10.1016/j.agsy.2014.08.005

Temme A, Verburg PH (2011) Mapping and modelling of changes in agricultural intensity in Europe. Agric Ecosyst Environ 140(1):4656. https://doi.org/10.1016/j.agee.2010.11.010

Thomson AM, Ellis EC, Grau HR, Kuemmerle T, Meyfroidt P, Ramankutty N, Zeleke G (2019) Sustainable intensification in land systems: trade-offs, scales, and contexts. Curr Opin Environ Sustain 38:37-43. https://doi.org/10.1016/j.cosust.2019.04.011

Thünen Institut (2014) Der Thünen Agraratlas. https://www.thuenen.de/ de/infrastruktur/thuenen-atlas-und-geoinformation/thuenen-atlas/. Accessed 23 Jan 2020

Tieskens KF, Schulp CJ, Levers C, Lieskovský J, Kuemmerle T, Plieninger T, Verburg PH (2017) Characterizing European cultural landscapes: accounting for structure, management intensity and value of agricultural and forest landscapes. Land Use Policy 62:29-39. https://doi.org/10.1016/j.landusepol.2016.12.001

Tkaczynski A (2017) Segmentation using two-step cluster analysis. In: Dietrich T, Rundle-Thiele S, Kubacki K (eds) Segmentation in social marketing: process, methods and application. Springer, Singapore, pp 109-125. https://doi.org/10.1007/978-981-10-1835-0_8

Tomlinson SJ, Dragosits U, Levy PE, Thomson AM, Moxley J (2018) Quantifying gross vs. net agricultural land use change in Great Britain using the integrated administration and control system. Sci Total Environ 628-629:1234-1248. https://doi.org/10.1016/j.scito tenv.2018.02.067

Troegel T, Schulz C (2018) Ergebnisse der Agrarstrukturerhebung 2016 für das Land Brandenburg. Zeitschrift Für Amtliche Statistik. https:// www.statistik-berlin-brandenburg.de/publikationen/aufsaetze/2018/ HZ_201801-08.pdf. Accessed 1 Mar 2020

Tscharntke T, Klein AM, Kruess A, Steffan-Dewenter I, Thies C (2005) Landscape perspectives on agricultural intensification and biodiversity: ecosystem service management. Ecol Lett 8(8):857-874. https://doi.org/10.1111/j.1461-0248.2005.00782.x

Uthes S, Kelly E, König HJ (2020) Farm-level indicators for crop and landscape diversity derived from agricultural beneficiaries data. Ecol Ind 108:105725. https://doi.org/10.1016/j.ecolind.2019.105725

Uuemaa E, Mander Ü, Marja R (2013) Trends in the use of landscape spatial metrics as landscape indicators: a review. Ecol Ind 28:100-106. https://doi.org/10.1016/j.ecolind.2012.07.018

Václavík T, Lautenbach S, Kuemmerle T, Seppelt R (2013) Mapping global land system archetypes. Glob Environ Change 23(6):16371647. https://doi.org/10.1016/j.gloenvcha.2013.09.004 
van der Zanden EH, Levers C, Verburg PH, Kuemmerle T (2016) Representing composition, spatial structure and management intensity of European agricultural landscapes: a new typology. Landsc Urban Plann 150:36-49. https://doi.org/10.1016/j.landurbplan.2016.02.005

Vaz E, de Noronha T, Nijkamp P (2014) Exploratory landscape metrics for agricultural sustainability. Agroecol Sustain Food Syst 38(1):92108. https://doi.org/10.1080/21683565.2013.825829

Venghaus S, Acosta L (2018) To produce or not to produce: an analysis of bioenergy and crop production decisions based on farmer typologies in Brandenburg, Germany. Reg Environ Change 18(2):521-532. https://doi.org/10.1007/s10113-017-1226-1

Vergara F, Lakes T (2019) Maizification of the landscape for biogas production. Diskussionspapier. https://doi.org/10.18452/20977
Weissteiner CJ, García-Feced C, Paracchini ML (2016) A new view on EU agricultural landscapes: quantifying patchiness to assess farmland heterogeneity. Ecol Ind 61:317-327. https://doi.org/10.1016/j. ecolind.2015.09.032

Wu J (2004) Effects of changing scale on landscape pattern analysis: scaling relations. Landsc Ecol 19(2):125-138. https://doi.org/10.1023/B: LAND.0000021711.40074.ae

Zasada I, Loibl W, Berges R, Steinnocher K, Köstl M, Piorr A, Werner A (2013) Rural-urban regions: a spatial approach to define urban-rural relationships in Europe. In: Nilsson K (ed) Peri-urban futures: Scenarios and models for land use change in Europe. Springer, Berlin, pp 45-68. https://doi.org/10.1007/978-3-642-30529-0_3 